\title{
$\alpha$-Tocopherol Prevents Sperm Apoptosis and Necrosis in Rats Exposed to 2,3,7,8-Tetrachlorodibenzo-p-dioxin
}

\author{
Dewa Ketut Meles $(D),{ }^{1}$ Kadek Rachmawati $(D),{ }^{1}$ Iwan Sahrial Hamid ${ }^{D},{ }^{1}$ Imam Mustofa $(D), 2$ \\ Wurlina Wurlina $\mathbb{D}^{2},{ }^{2}$ Niluh Suwasanti $\mathbb{D}^{3}$, Desak Ketut Sekar Cempaka Putri $\mathbb{D}^{4}{ }^{4}$ \\ and Suzanita Utama $\mathbb{D}^{2}$ \\ ${ }^{1}$ Laboratory of Veterinary Pharmacology, Faculty of Veterinary Medicine, Airlangga University, Kampus C Mulyorejo, \\ Surabaya 60115, Indonesia \\ ${ }^{2}$ Division of Veterinary Reproduction, Faculty of Veterinary Medicine, Airlangga University, Kampus C Mulyorejo, \\ Surabaya 60115, Indonesia \\ ${ }^{3}$ Department of Clinical Pathology, Widya Mandala Surabaya Catholic University, \\ Jl. Kalisari Selatan No. 1, Kalisari, Kec. Mulyorejo, Surabaya 60112, Indonesia \\ ${ }^{4}$ Division of Cardiology, Faculty of Medicine, Airlangga University, Jl. Mayjen Prof. Dr. Moestopo No. 47, \\ Surabay 60132, Indonesia \\ Correspondence should be addressed to Suzanita Utama; suzanita-u@fkh.unair.ac.id
}

Received 8 October 2021; Accepted 2 February 2022; Published 21 February 2022

Academic Editor: Sumanta Nandi

Copyright (c) 2022 Dewa Ketut Meles et al. This is an open access article distributed under the Creative Commons Attribution License, which permits unrestricted use, distribution, and reproduction in any medium, provided the original work is properly cited.

\begin{abstract}
2,3,7,8-tetrachlorodibenzo-p-dioxin (TCDD) is a persistent organic pollutant that induces overproduction of reactive oxygen species (ROS). Studies on avoiding the adverse effects of dioxin pollution exposure are needed in all aspects, including reproductive health. This study aimed to determine the effect of $\alpha$-tocopherol on superoxide dismutase (SOD) and malondialdehyde (MDA) levels, live spermatozoa, apoptosis, and necrosis in male rats exposed to dioxin as a model. Thirty healthy 12 -week-old male rats were randomly divided into five groups. Rats in the control group were given corn oil twice daily at 4-hour intervals. The remaining rats were given TCDD $700 \mathrm{mg} / \mathrm{kg} \mathrm{BW}$ daily, followed by administration of corn oil and $\alpha$-tocopherol at doses of 77,140 , and $259 \mathrm{mg} / \mathrm{kg} \mathrm{BW} / \mathrm{d}$ for T0, T1, T2, and T3 groups, respectively. The treatments were conducted for 45 days; all rats were euthanized to collect blood and testicular samples on day 46. The results showed that exposure of TCDD resulted in a decrease in SOD activity and live spermatozoa and increased MDA level and death, apoptosis, and necrosis of spermatozoa (T0) compared to the control (C) group ( $p<0.05$ ). The administration of $\alpha$-tocopherol, starting from the doses of 77 (T1), 149 (T2), and 259 mg (T3) per $\mathrm{kg}$ BW, was sequentially followed by returning MDA levels, recovering SOD activities, and restoration in the percentage of living, dead, apoptotic, and necrotic spermatozoa, similar $(p>0.05)$ to those of the control group. It could be concluded that the administration of $\alpha$-tocopherol resolves the harmful effects of TCDD on the viability of spermatozoa in rats as a model.
\end{abstract}

\section{Introduction}

The formation of 2,3,7,8-tetrachlorodibenzo-p-dioxin (TCDD) was as a by-product in the burning processes of organic materials or a side product in organic synthesis. It was a persistent organic pollutant and a colorless solid with no distinguishable odor at room temperature [1]. TCDD induced premature senescence in neuronal cells by promoting intracellular ROS production that accelerates the onset of neuronal senescence to induce neurotoxic effects [2]. The neuroendocrine activity along the hypothalamicpituitary-testicular axis regulated spermatogenesis [3]. A reverse set of changes in the AhR protein and mRNA response to TCDD suggested that AhR functions as a physiological regulator [4]. Our previous study indicated that TCDD depressed spermatogenic staging, number of Leydig 
cells, spermatozoa, seminiferous tubule diameter, and thickness of tubule epithelium [5]. TCDD caused mitochondrial dysfunction and the accumulation of cellular reactive oxygen species (ROS) [2]. Polyunsaturated fatty acids in the cell membrane, including the membrane of mitochondria, are sensitive to ROS exposure, causing lipid peroxidation. The end product of lipid peroxidation was MDA; therefore, MDA was a biomarker for oxidative stress [6].

In living beings, there are several endogenous antioxidants, including SOD. SOD is essential for protecting cells against oxidative stress [7]. The antioxidant matter can scavenge free radicals due to TCDD [8]. Meanwhile, $\alpha$-tocopherol is an exogenous antioxidant, a fat-soluble nonenzymatic antioxidant. The antioxidant $\alpha$-tocopherol can break the TCDD chain bond with AhR (aryl hydrocarbon receptor) found in the cell cytoplasm, thus protecting cells from lipid peroxidation [7]. $\alpha$-tocopherol was a fertility triggering agent that can normalize seminiferous tubular epithelium [9] and had a protective effect on oxidative stress and sperm apoptosis in diabetic mice [10]. The administration of $\alpha$-tocopherol proved to repair the damage of testicle histology in rats exposed to dioxin [5]. The decreasing spermatogenic staging due to TCDD exposure may be caused by the death of sperm due to apoptosis and necrosis. There is no report about the use of $\alpha$-tocopherol to avoid apoptosis and necrosis of spermatozoa on rats exposed to TCDD.

Therefore, this study aimed to determine the effect of $\alpha$-tocopherol for maintaining sperm viability, decreasing sperm apoptosis and necrosis through maintaining SOD, and decreasing MDA levels on male rats exposed to dioxin.

\section{Materials and Methods}

2.1. Ethical Approval. The experimental protocol of this study was approved by the Animal Care and Use Committee, Airlangga University, Surabaya, Indonesia (no. 267/ HRECC.FORM/VI/2020). Experiments have been conducted with minimum pain or discomfort, following the guidelines established by the Institutional Animal Ethics Committee.

2.2. TCDD and $\alpha$-Tocopherol Dosages. The dose determination of TCDD and $\alpha$-tocopherol (both from SigmaAldrich, Singapore) was based on our earlier study [5]. This study used a single dose of $700 \mathrm{ng} / \mathrm{kg}$ BW/day TCDD. Meanwhile, the doses of $\alpha$-tocopherol were 77, 140, and $259 \mathrm{mg} / \mathrm{kg} /$ day. Corn oil (Mazola ${ }^{\circledR}$, Codaa Switzerland AG) was used as a solvent for TCDD and $\alpha$-tocopherol.

2.3. Treatment of Experimental Animals. Thirty healthy male rats (Rattus norvegigus, Wistar strain) aged 12 weeks, weighing about 200 grams, were randomly divided into five groups equally for control (C), T1, T2, T3, and T4 group. The control group rats were administered corn oil twice a day in four-hour intervals. The remaining rats in the treatment group were given TCDD $700 \mathrm{mg} / \mathrm{kg} \mathrm{BW/day,} \mathrm{and} \mathrm{four} \mathrm{hours}$ later, they were given corn oil, $\alpha$-tocopherol 77, 140, and $259 \mathrm{mg} / \mathrm{kg}$ BW/day for the T0, T1, T2, and T3 groups, respectively. TCDD and $\alpha$-tocopherol were administered orally in $1 \mathrm{~mL}$ volume daily for 45 days, and on day 46 , all rats were euthanized for blood and testicular samples. Euthanasia was performed via decapitation by trained personnel.

2.4. SOD Activity Measurements. The tunica albuginea of the testes was removed; then, the testes were homogenized at a ratio of one gram tissue per $\mathrm{ml}$ of $0.05 \mathrm{M}$ Tris- $\mathrm{HCl}$ buffer $\mathrm{pH}$ 7.5. The homogenate was centrifuged at $12000 \times \mathrm{g}$ for 15 minutes to remove most of the tubules and other large sediment tissue fragments. The supernatant was centrifuged for 20 minutes at $50,000 \times \mathrm{g}$ and $150,000 \times \mathrm{g}$ for 60 minutes. The lipid layer on the surface of the supernatant was removed after each centrifugation, and the final supernatant was used for SOD activity measurement using a colorimetric superoxide dismutase activity assay kit (CS0009, SigmaAldrich, Singapore) at a wavelength of $550 \mathrm{~nm}$ [11].

2.5. MDA Level Measurements. Blood samples were collected from below the aortic arch for measuring serum MDA levels using the thiobarbituric acid-reactive substance (Sigma-Aldrich, Singapore) with a UV-1601 spectrophotometer at a maximum wavelength of $535 \mathrm{~nm}[12,13]$.

2.6. Live and Dead Spermatozoa Count. Semen was collected from the cauda epididymis and diluted 200 times with $0.9 \%$ $\mathrm{NaCl}$. A drop of the semen sample and a drop of eosinnigrosin were mixed homogeneously, smeared, and quickly dried over the flame. The viability of the sperm was examined under a light microscope Nikon E200 (Nikon Corporation, Tokyo, Japan) at $400 \times$ magnification. Live spermatozoa were white and transparent on the head since they did not absorb color, while the dead spermatozoa absorbed a red-purple color [14]. The percentages of live and dead spermatozoa were determined out of the total of 300 spermatozoa.

2.7. Apoptosis and Necrosis Spermatozoa Count. Dry smeared semen samples were fixed with absolute methanol and glacial acid for $15 \mathrm{~min}$, stained with acridine orange, and then observed with a fluorescence microscope at 100x (Nikon Eclipse E800, Tokyo, Japan). Apoptotic spermatozoa were yellow to reddish, and the necrotic ones were brownish-orange. Meanwhile, live spermatozoa were greenstained $[15,16]$. The percentages of apoptosis and necrosis spermatozoa were determined out of the total of 300 spermatozoa.

2.8. Statistical Analysis. The data were analyzed using a oneway ANOVA followed by Tukey's honestly significant difference test at a 95\% confidence level (SPSS version 23, IBM, New York, United States). 


\section{Results}

TCDD exposure was followed by a decrease in SOD activity by half and an increase in MDA levels twice (T0) compared to the control group (C) $(p<0.05)$. Administration of $\alpha$-tocopherol starting at a dose of $140 \mathrm{mg}$ per $\mathrm{kg}$ BW restored the same SOD activity as in the normal mice (group C) (Table 1).

Different superscripts in the same column show significant differences $(p<0.05)$. Rats in the control group (C) were administered $0.5 \mathrm{~mL}$ of corn oil twice daily at $4 \mathrm{~h}$ intervals for $45 \mathrm{~d}$. Rats in groups T0, T1, T2, and T3 were administered TCDD $700 \mathrm{ng} / \mathrm{kg}$ BW daily and $4 \mathrm{~h}$ later were administered corn oil, 77,140 , and $259 \mathrm{mg} / \mathrm{kg}$ BW daily $\alpha$-tocopherol, respectively, for $45 \mathrm{~d}$.

3.1. Live, Dead, Apoptotic, and Necrotic Spermatozoa. Rats exposed to TCDD (T0 group) showed decreases of live spermatozoa (leaving only about $40 \%$ ) and 4 -5-fold increases, respectively, in dead, apoptotic, and necrotic spermatozoa compared to normal rats (C group) $(p<0.05)$. Administration of $\alpha$-tocopherol resulted in increased live spermatozoa. The dose of $259 \mathrm{mg} \alpha$-tocopherol per kg BW recovered all of those parameters to those of the control group $(p>0.05)$ (Table 2 and Figures 1 and 2).

Different superscripts in the same column show significant differences $(p<0.05)$. Rats in the control group (C) were administered $0.5 \mathrm{~mL}$ of corn oil twice daily at $4 \mathrm{~h}$ intervals for $45 \mathrm{~d}$. Rats in groups $\mathrm{T} 0, \mathrm{~T} 1, \mathrm{~T} 2$, and $\mathrm{T} 3$ were administered TCDD $700 \mathrm{ng} / \mathrm{kg}$ BW daily and $4 \mathrm{~h}$ later were administered corn oil, 77, 140, and $259 \mathrm{mg} / \mathrm{kg}$ BW daily $\alpha$-tocopherol, respectively, for $45 \mathrm{~d}$.

\section{Discussion}

TCDD is a toxic substance that induces oxidative stress, which is an imbalance between free radicals and antioxidants [8]. Free radicals react with polyunsaturated fatty acids, resulting in lipid peroxidation [17]. MDA was a marker of lipid peroxidation [18]. Lipid peroxidation is a degenerative process that plays a crucial role in the pathogenesis of many diseases by decomposing hydroperoxide products into cytotoxic derivatives [19]. Actually, there are many antioxidants in the living cell as a defense mechanism against the oxidant, such as superoxide dismutase (SOD), catalase (CAT), and seleno-dependent glutathione peroxidase (GSHPx) [20]. However, those antioxidant levels decrease when there is excessive free radical production [21].

4.1. SOD and MDA. The SOD activities were lower in rats exposed to TCDD (T0) than those of normal rats. TCDD activated the aryl hydrocarbon receptor (AhR) and led to dimerization with the aryl hydrocarbon receptor nuclear translocator (ARNT) and transcriptional activation of several xenobiotic-metabolizing enzymes, such as SOD. SOD was essential for protecting cells against the harmful superoxide radical derived from mitochondrial respiratory chain leakage. SOD causes the dismutation of the superoxide radicals to molecular oxygen and hydrogen peroxide $[7,13]$.
SOD inactivation was resulted from oxidative stress due to excessive reactive oxygen species (ROS) [22]. Administration of $\alpha$-tocopherol, starting from $140 \mathrm{mg}$ per $\mathrm{kg} \mathrm{BW}$, was sufficient to restore the SOD activity level to that of the normal rats. This may be due to the antioxidant of $\alpha$-tocopherol scavenges excess free radicals in cells, preventing SOD inactivation [20].

The MDA level of rats exposed to TCDD were higher than those of normal rats. Polyunsaturated fatty acids of the cell membrane easily accepted unpaired electrons from ROS, causing lipid peroxidation [6]. The end product of lipid peroxidation was MDA; therefore, MDA was a biomarker for oxidative stress [23]. The increased MDA levels in rats exposed to TCDD reflect the level of damage to the plasma membrane attacked by free radicals. When ROS levels were higher than endogenous antioxidants (among others is SOD), membrane integrity was lost, and MDA levels increased. Administration of $\alpha$-tocopherol starting from $77 \mathrm{mg}$ per $\mathrm{kg} \mathrm{BW}$ was sufficient to return MDA levels like those of normal rats. The result of this study was following the earlier report of the higher antioxidant level, followed by the lower MDA levels [24].

4.2. Live Spermatozoa. In the control group, about $14-15 \%$ of the spermatozoa population died. The normal metabolic activity could also cause death in the spermatozoa itself because the lactic acid produced lowered semen $\mathrm{pH}$ [25]. The rat sperm viability decreased along with increasing the dead, apoptotic, and necrotic spermatozoa due to the TCDD exposure. A substantial decrease in the quality of spermatozoa occurred due to a large number of dead spermatozoa [26]. Short-term exposure to TCDD has been shown to affect live spermatozoa [27]. TCDD elicits its effects by inducing AhR degradation and requires ubiquitination of the protein as a mechanism of mediated gene induction [28]. Sperm DNA fragmentation due to increased ROS affected live spermatozoa [29]. TCDD also inhibited the action of the 17$\beta$-hydroxysteroid oxidoreductase enzyme in testosterone synthesis, causing a decrease in testosterone levels. Testosterone was essential in maintaining the viability of spermatozoa as long as they are stored in the epididymis [30-32].

$\alpha$-tocopherol could protect the health of the mitochondrial plasma membrane to maintain the viability of spermatozoa [33]. In this study, a dose of $259 \mathrm{mg} / \mathrm{kg} \mathrm{BW} / \mathrm{d}$ $\alpha$-tocopherol completely covered the effects of TCDD on sperm viability. The antioxidant effects of $\alpha$-tocopherol worked not only at the spermatogenesis stage but also during endocrine regulation that maintains spermatozoa's viability [33]. $\alpha$-tocopherol is a fat-soluble antioxidant, so it is more effective as a protector against oxidative stress [34], and it scavenges ROS and stops the chain propagation reaction in the lipid peroxidation process $[9,10]$ due to TCDD is also fat-soluble. Therefore, $\alpha$-tocopherol is essential in maintaining the physiological integrity of the testicular cells, epididymis, and accessory glands that play essential roles in spermatogenesis and the maturation and viability of spermatozoa $[35,36]$. These results were consistent with the findings of Ghafarizadeh et al. [37] that $\alpha$-tocopherol increases sperm viability in vitro. 
TABLe 1: SOD activity (\%) and MDA level $(\mathrm{nm} / \mathrm{mL})$ of rats exposed to TCDD and treated with $\alpha$-tocopherol.

\begin{tabular}{lcc}
\hline Group & SOD & MDA \\
\hline C & $73.66 \pm 10.35^{\mathrm{a}}$ & $4.17 \pm 0.85^{\mathrm{b}}$ \\
T0 & $32.64 \pm 3.12^{\mathrm{c}}$ & $9.68 \pm 1.65^{\mathrm{a}}$ \\
T1 & $56.32 \pm 3.07^{\mathrm{b}}$ & $3.24 \pm 0.34^{\mathrm{b}}$ \\
T2 & $65.46 \pm 2.73^{\mathrm{a}}$ & $4.04 \pm 0.61^{\mathrm{b}}$ \\
T3 & $68.27 \pm 5.07^{\mathrm{a}}$ & $4.61 \pm 0.25^{\mathrm{b}}$ \\
\hline
\end{tabular}

TABLE 2: The percentage of live, dead, apoptotic, and necrotic spermatozoa (\%) of rats exposed to TCDD and treated with $\alpha$-tocopherol.

\begin{tabular}{lcccc}
\hline Group & Live spermatozoa & Dead spermatozoa & Apoptotic spermatozoa & Necrotic spermatozoa \\
\hline C & $85,44 \pm 3,71^{\mathrm{a}}$ & $14.56 \pm 3,97^{\mathrm{c}}$ & $8,32 \pm 2,26^{\mathrm{c}}$ & $6,24 \pm 2,00^{\mathrm{c}}$ \\
T0 & $33,84 \pm 4,41^{\mathrm{c}}$ & $66.16 \pm 5,05^{\mathrm{a}}$ & $35,43 \pm 6,05^{\mathrm{a}}$ & $30,73 \pm 4,31^{\mathrm{a}}$ \\
T1 & $65,55 \pm 4,19^{\mathrm{b}}$ & $34.45 \pm 6,62^{\mathrm{b}}$ & $18,44 \pm 2,41^{\mathrm{b}}$ & $16,01 \pm 3,54^{\mathrm{b}}$ \\
T2 & $72,76 \pm 4,8 \mathrm{a}^{\mathrm{b}}$ & $27.24 \pm 6,09^{\mathrm{b}}$ & $14,08 \pm 3,42^{\mathrm{b}}$ & $13,16 \pm 2,76^{\mathrm{b}}$ \\
T3 & $81,82 \pm 2,93^{\mathrm{a}}$ & $18.18 \pm 3,82^{\mathrm{c}}$ & $9,51 \pm 2,17^{\mathrm{c}}$ & $8,67 \pm 1,94^{\mathrm{c}}$ \\
\hline
\end{tabular}

4.3. Necrosis and Apoptosis. Cell death could be caused by apoptosis and necrosis; both could be induced by toxic substances [38], including overproduction of ROS [39]. Staining with ethidium bromide and acridine orange in necrotic cells made all the cells appear brown $[16,40]$. In apoptotic cells, not all dyes could enter the cell because the cell membrane was still intact, but the DNA was fragmented $[41,42]$ and stained so that the nucleus is yellow with brownish-red cytoplasm $[16,40]$. Necrosis was an acute and irreversible cell death due to damage to the plasma membrane that could not maintain homeostasis to allow the entry of water and extracellular ions [43]. Cell necrosis may occur due to the activity of the lysozyme that digests the cell membrane's organelles, such as the mitochondrial membrane, ribosomes, and other cell apparatus, including intracytoplasmic fluid, followed by cell lysis [44]. However, the cell damage was reversible if the cause was immediately removed [45]. Apoptosis was a programmed cell death that was not preceded by cell swelling or inflammation. Apoptotic cells would shrink due to a breakup of the cell nucleus and chromosomes, which all form apoptotic bodies [46]. The mitochondrial membrane was rich in lipids sensitive to free radical attack [47]. In the mitochondrial membrane, there were $\mathrm{Bcl}-2$ or $\mathrm{Bcl}-\mathrm{XL}$ proteins that bound to Bax proteins that regulate the mechanism of apoptosis [48]. The apoptosis is triggered by lipid peroxidation, which leads to ROS activation in a continuous redox cycle. This cascade also includes the increased activity of a p53 protein, which will activate the Bax protein and then stimulate mitochondria to produce excessive cytochrome $\mathrm{c}$ that will cause apoptosis [44]. Cytochrome $\mathrm{c}$ is made up of apoptogenic proteins, such as the apoptosis-inducing factor and the endonuclease $G$ [35], followed by caspase activation and exposure to phosphatidylserine on the surface of spermatozoa a few hours later [49]. The increasing ROS affected the damage of DNA, especially the integrity of DNA as a cause of cell death [50], and caused the limited cytoplasmic capacity for DNA repair. The higher DNA fragmentation correlated with the activation of caspase-3 [51] as the executioner of apoptosis
[52]. Antioxidant effect of $\alpha$-tocopherol at $259 \mathrm{mg} / \mathrm{kg} \mathrm{BW}$ recovers live, dead, necrosis, and apoptosis of spermatozoa which returns to like those of normal rats.

An increase in MDA levels and a decrease in SOD indicated oxidative stress followed by cell death mechanisms, such as apoptosis or necrosis [53]. Administration of $\alpha$-tocopherol started from a dose of 77 and $140 \mathrm{mg}$ per $\mathrm{kg}$ BW, returning MDA levels and SOD activity to those of normal rats. However, a dose of $259 \mathrm{mg} / \mathrm{kg} \mathrm{BW} \alpha$-tocopherol was needed to recover the percentage of living, dead, apoptosis, and necrosis of spermatozoa. This may be due to the effect of TCDD on sperm viability, and its recovery by $\alpha$-tocopherol requires a more complicated mechanism and extended pathway than are needed to recover MDA levels and SOD activity. The maintaining of testicle health involves the dynamics of complex upregulation of the endocrine. The explanation of $\alpha$-tocopherol role for recovery testicular damage due to TCDD exposure in this study was limited based on SOD and MDA levels. Therefore, further studies were needed to determine changes in GnRH, FSH, LH, and testosterone levels, including the role of $\alpha$-tocopherol to prevent apoptosis of testicular tissue at gene level such as $\mathrm{AhR}, \mathrm{Bax}$, and $\mathrm{Bcl}$ casp3.

Necrosis is acute and irreversible cell death due to damage to the plasma membrane that cannot maintain homeostasis to allow the entry of water and extracellular ions [43]. Cell necrosis may occur due to the activity of the lysozyme that digests the cell membrane's organelles, such as the mitochondrial membrane, ribosomes, and other cell apparatus, including intracytoplasmic fluid; damage is caused to the cells, followed by cell lysis [44]; however, the cell damage is reversible if the cause is immediately removed [45]. Administration of $\alpha$-tocopherol starts from a dose of 77 and $140 \mathrm{mg}$ per $\mathrm{kg} \mathrm{BW}$, returning MDA levels and SOD activity to those of normal rats. MDA levels and SOD activity of rats exposed to TCDD and treated with $\alpha$-tocopherol at dose 140 or $259 \mathrm{mg} / \mathrm{kg} \mathrm{BW}$ daily were not statistically significant $(p>0.05)$ than those of normal rats (control group). 


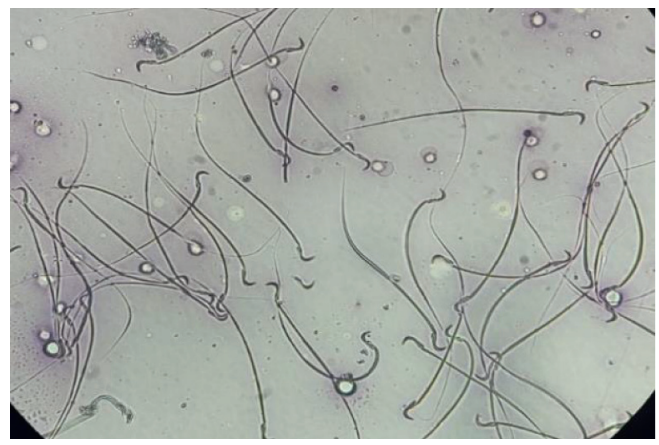

C

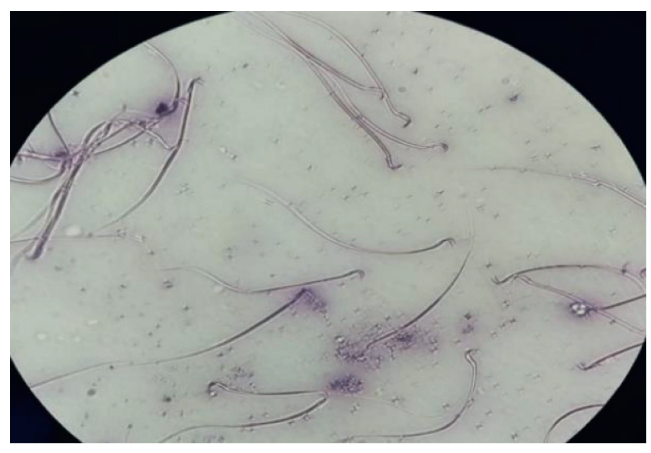

T0

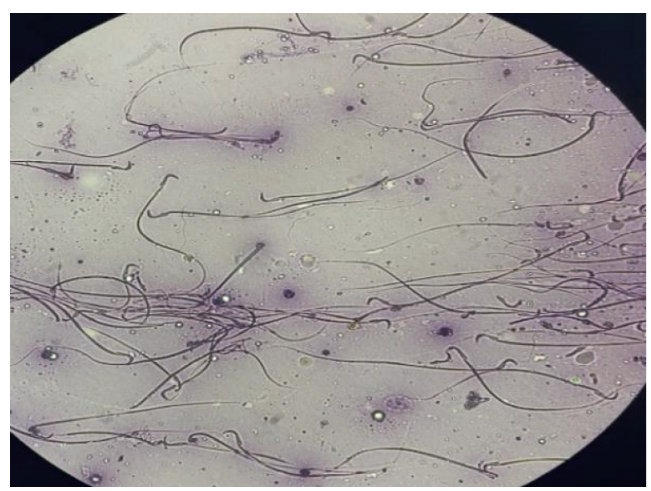

T3

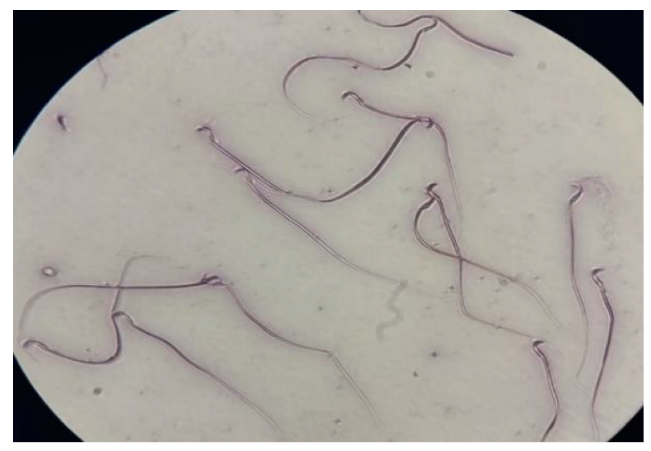

T1

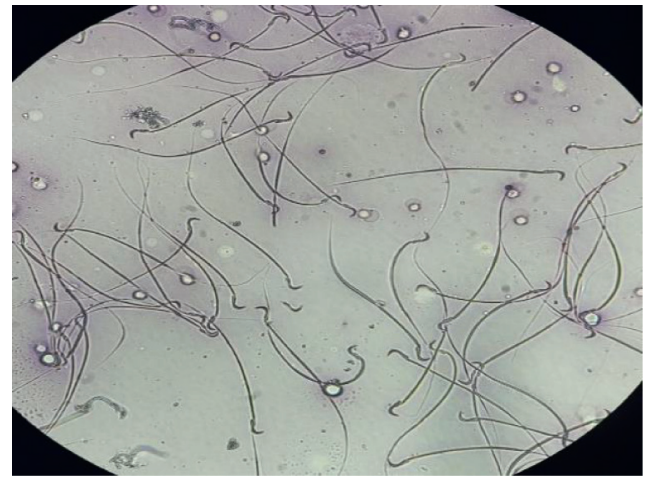

T4

Figure 1: Live and dead sperm of rat exposed to TCDD and treated with $\alpha$-tocopherol. Rats in the control group (C) were administered $0.5 \mathrm{~mL}$ of corn oil twice daily at $4 \mathrm{~h}$ intervals for $45 \mathrm{~d}$ Rats in groups T0, T1, T2, and T3 were administered TCDD $700 \mathrm{ng} / \mathrm{kg}$ BW daily and $4 \mathrm{~h}$ later were administered corn oil, 77, 140, and $259 \mathrm{mg} / \mathrm{kg}$ BW daily $\alpha$-tocopherol, respectively, for $45 \mathrm{~d}$ Live spermatozoa do not absorb color on the head, whereas dead spermatozoa absorb a red-purple color from the stain (eosin-nigrosin staining), at 400× magnification under a light microscope Nikon E200 (Tokyo, Japan). 


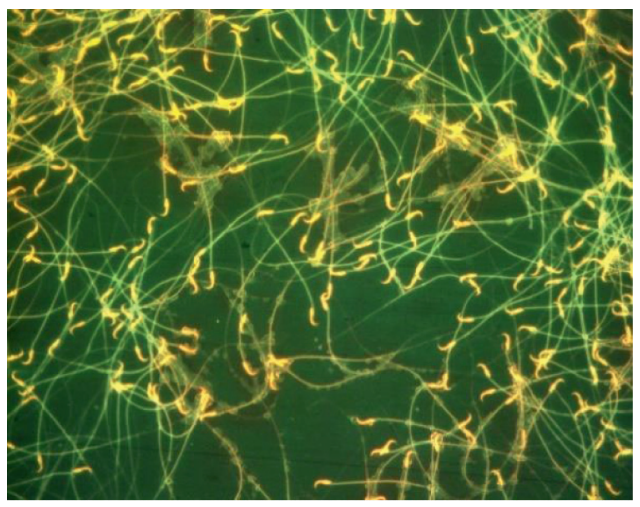

C

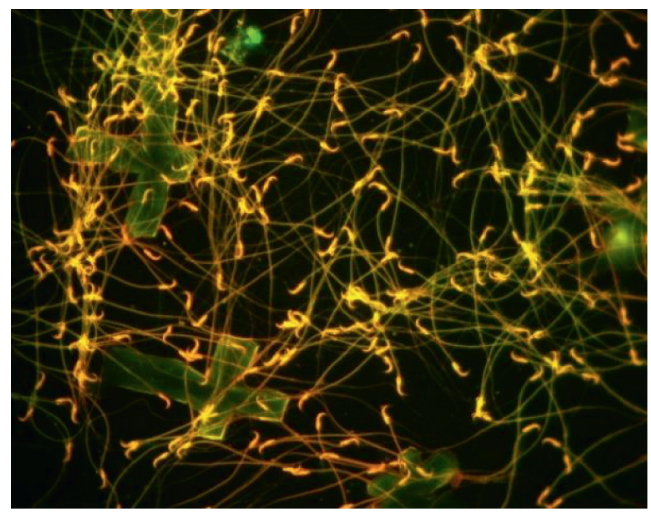

T0

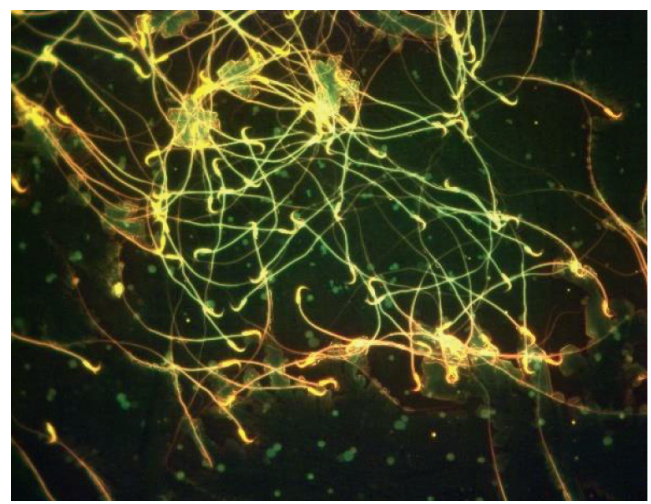

T3

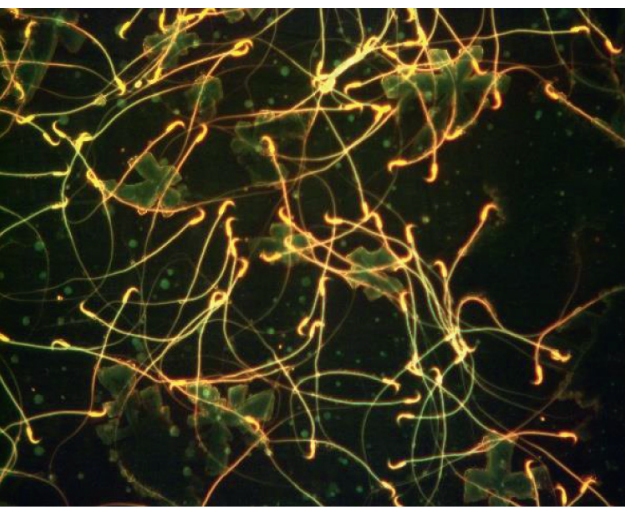

$\mathrm{T} 1$

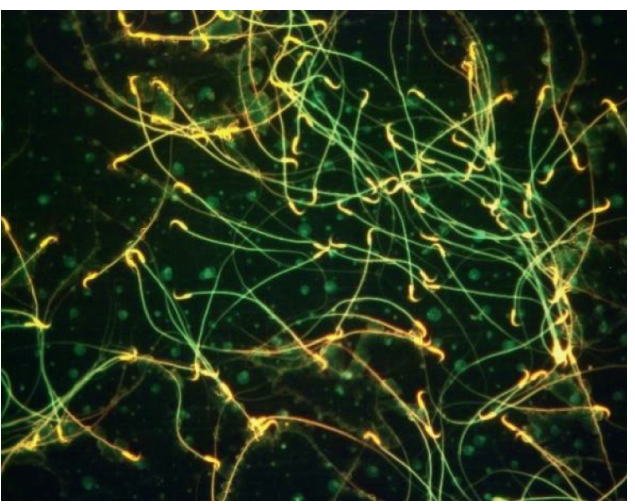

$\mathrm{T} 4$

Figure 2: Apoptotic and necrotic spermatozoa of rats exposed to TCDD and treated with $\alpha$-tocopherol. Rats in the control group (C) were administered $0.5 \mathrm{~mL}$ of corn oil twice daily at $4 \mathrm{~h}$ intervals for $45 \mathrm{~d}$. Rats in groups T0, T1, T2, and T3 were administered TCDD $700 \mathrm{ng} / \mathrm{kg}$ BW daily and $4 \mathrm{~h}$ later were administered corn oil, 77,140 , and $259 \mathrm{mg} / \mathrm{kg}$ BW daily $\alpha$-tocopherol, respectively, for $45 \mathrm{~d}$. The membrane of apoptotic spermatozoa will be green with yellowish cytoplasm and nucleus, and necrotic spermatozoa will be brown. Meanwhile, live spermatozoa were green (acridine orange staining), at 100× magnification under a fluorescence microscope (Nikon Eclipse E800, Tokyo, Japan). 


\section{Conclusion}

$\alpha$-tocopherol rebalances SOD and MDA levels to recover spermatozoa's viability from necrosis and apoptosis death of male rats exposed to TCDD.

\section{Data Availability}

The data used to support the findings of this study are available from the first author.

\section{Conflicts of Interest}

The authors declare that there are no conflicts of interest.

\section{Authors' Contributions}

DKM, IM, and WW compiled ideas, designed the research work, and provided the draft manuscript. KR, ISH, and WW performed treatment of rats. NS and SU measured SOD activity and MDA levels. DKM, DKSCP, and KR evaluated viability, apoptosis, and necrosis of spermatozoa. DKM and IM conducted the statistical analysis and conceived the manuscript. ISH, NS, DKSCP, and SU critically read and revised the manuscript for intellectual content. All authors read and approved the final manuscript.

\section{Acknowledgments}

The authors would like to thank the Directorate of Research and Community Service, Deputy for Strengthening Research and Technology, Ministry of Research and Technology/ National Research and Innovation Agency for the fiscal year 2021 and Basic Research Scheme for Higher Education Excellence PDUPT Fiscal Year 2021 (number: 431/Un3.15/ $\mathrm{Pt} / 2021$ ). The authors also thank Bapak Supardi, the keeper of research animals, and Bapak Jumawan, the laboratory technician at the Division of Veterinary Pathology, Faculty of Veterinary Medicine, Universitas Airlangga, for all assistance during the research.

\section{References}

[1] J. Tuomisto, "Dioxins and dioxin-like compounds: toxicity in humans and animals, sources, and behaviour in the environment," WikiJournal of Medicine, vol. 6, no. 1, p. 8, 2019.

[2] C. Wan, J. Liu, X. Nie et al., "2, 3, 7, 8-Tetrachlorodibenzo-Pdioxin (TCDD) induces premature senescence in human and rodent neuronal cells via ROS-dependent mechanisms," PLoS One, vol. 9, no. 2, Article ID e89811, 2014.

[3] S. Ramaswamy and G. F. Weinbauer, "Endocrine control of spermatogenesis: role of FSH and LH/testosterone," Spermatogenesis, vol. 4, no. 2, Article ID e996025, 2015.

[4] J. Lindén, S. Lensu, and R. Pohjanvirta, "Effect of 2,3,7,8tetrachlorodibenzo-p-dioxin (TCDD) on hormones of energy balance in a TCDD-sensitive and a TCDD-resistant rat strain," International Journal of Molecular Sciences, vol. 15, no. 8, pp. 13938-13966, 2014.

[5] W. Wurlina, I. Mustofa, D. K. Meles, S. Mulyati, D. K. S. C. Putri, and N. Suwasanti, "Administration of the $\alpha$-tocopherol for repairing testicle histological damage in rats exposed to dioxin," Thai Journal of Veterinary Medicine, vol. 51, no. 2, pp. 293-301, 2021.

[6] H. Wagner, J. W. Cheng, and E. Y. Ko, "Role of reactive oxygen species in male infertility: an updated review of literature," Arab Journal of Urology, vol. 16, no. 1, pp. 35-43, 2018.

[7] C. Dietrich, "Antioxidant functions of the aryl hydrocarbon receptor," Stem Cells International, vol. 2016, pp. 1-10, 2016.

[8] O. Ciftci, A. B. Duman, N. S. Turkmen, and A. Taslıdere, "Beta-glucan prevents toxic effects of 2,3,7,8-TCDD in terms of oxidative and histopathological damage in heart tissue of rats," Brazilian Journal of Pharmaceutical Sciences, vol. 54, no. 3, pp. 1-7, 2018.

[9] M. Górnicka, A. Ciecierska, J. Hamulka et al., “ $\alpha$-Tocopherol protects the heart, muscles, and testes from lipid peroxidation in growing male rats subjected to physical efforts," Oxidative Medicine and Cellular Longevity, vol. 2019, no. 7, 13 pages, Article ID 8431057, 2019.

[10] K. M. Khorramabadi, A. R. Talebi, A. A. Sarcheshmeh, and A. Mirjalili, "Protective effect of vitamin E on oxidative stress and sperm apoptosis in diabetic Mice," International Journal of Reproductive BioMedicine, vol. 17, no. 2, pp. 127-134, 2019.

[11] C. J. Weydert and J. J. Cullen, "Measurement of superoxide dismutase, catalase and glutathione peroxidase in cultured cells and tissue," Nature Protocols, vol. 5, no. 1, pp. 51-66, 2010.

[12] E. Fogarasi, M. D. Croitoru, I. Fülöp et al., "Malondialdehyde levels can be measured in serum and saliva by using a fast HPLC method with visible detection," Revista Romana de Medicina de Laborator, vol. 24, no. 3, pp. 2016-2029, 2016.

[13] I. L. Steensen, H. Dirven, S. Couderq et al., "Bisphenols and oxidative stress biomarkers-associations found in human studies, evaluation of methods used, and strengths and weaknesses of the biomarkers," International Journal of Environmental Research and Public Health, vol. 17, no. 10, p. 3609, 2020.

[14] S. Susilowati, I. N. Triana, W. Wurlina, A. Arimbi, P. Srianto, and I. Mustofa, "Addition of L-arginine in skim milk extender maintains goat spermatozoa quality in chilled temperature for five days," November-2019, Veterinary World, vol. 12, no. 11, pp. 1784-1789, 2019.

[15] C. Ortega-Ferrusola, L. Anel-López, P. Martín-Muñoz et al., "Computational flow cytometry reveals that cryopreservation induces spermptosis but subpopulations of spermatozoa may experience capacitation-like changes," Reproduction, vol. 153, no. 3, pp. 293-304, 2017.

[16] D. K. Wurlina, S. Safitri, A. Zakaria, D. K. Basori, and N. Suwasanti, "Effek of alkaloid of Achyranthes aspera linn (caryophyllales amaranthaceae) on increasing caspase 9, caspase 3 and apoptosos in mice with breast cancer," The Philippine Journal of Veterinary Medicine, vol. 1, no. 5, pp. 51-58, 2018.

[17] R. Domínguez, M. Pateiro, M. Gagaoua, F. J. Barba, W. Zhang, and J. M. Lorenzo, "A comprehensive review on lipid oxidation in meat and meat products," Antioxidants (Basel), vol. 8, no. 10, pp. 1-31, 2019.

[18] D. A. Cherian, T. Peter, A. Narayanan, S. S. Madhavan, S. Achammada, and G. P. Vynat, "Malondialdehyde as a marker of oxidative stress in periodontitis patients," Journal of Pharmacy \& Bioallied Sciences, vol. 11, no. S2, pp. S297-S300, 2019.

[19] Z. A. M. Zielinski and D. A. Pratt, "Lipid peroxidation: kinetics, mechanisms, and products," The Journal of Organic Chemistry, vol. 82, no. 6, pp. 2817-2825, 2017. 
[20] O. M. Ighodaro and O. A. Akinloye, "First line defence antioxidants-superoxide dismutase (SOD), catalase (CAT) and glutathione peroxidase (GPX): their fundamental role in the entire antioxidant defence grid," Alexandria Journal of Medicine, vol. 54, no. 4, pp. 287-293, 2018.

[21] A. Phaniendra, D. B. Jestadi, and L. Periyasamy, "Free radicals: properties, sources, targets, and their implication in various diseases," Indian Journal of Clinical Biochemistry, vol. 30, no. 1, pp. 11-26, 2015.

[22] Y. Wang, R. Branicky, A. Noë, and S. Hekimi, "Superoxide dismutases: dual roles in controlling ROS damage and regulating ROS signaling," Journal of Cell Biology, vol. 217, no. 6, pp. 1915-1928, 2018.

[23] S. Ahmed, M. I.-U.-R. Khan, M. Ahmad, and S. Iqbal, "Effect of age on lipid peroxidation of fresh and frozen-thawed semen of Nili-Ravi buffalo bulls," Italian Journal of Animal Science, vol. 17, no. 3, pp. 730-735, 2018.

[24] A. Kapusta, B. Kuczyńska, and K. Puppel, "Relationship between the degree of antioxidant protection and the level of malondialdehyde in high-performance Polish Holstein-Friesian cows in peak of lactation," PLoS One, vol. 13, no. 3, Article ID e0193512, 2018.

[25] S. Pesch, M. Bergmann, and H. Bostedt, "Determination of some enzymes and macro- and microelements in stallion seminal plasma and their correlations to semen quality," Theriogenology, vol. 66, no. 2, pp. 307-313, 2015.

[26] M. B. Nagata, J. Egashira, N. Katafuchi et al., "Bovine sperm selection procedure prior to cryopreservation for improvement of post-thawed semen quality and fertility," Journal of Animal Science and Biotechnology, vol. 10, no. 11, pp. 91-14, 2019.

[27] Y.-A. You, E. A. Mohamed, M. S. Rahman et al., "2,3,7,8Tetrachlorodibenzo-p-dioxin can alter the sex ratio of embryos with decreased viability of Y spermatozoa in mice," Reproductive Toxicology, vol. 77, no. 4, pp. 130-136, 2018.

[28] M. Ghotbaddini and J. Powell, "The AhR ligand, TCDD, regulates androgen receptor activity differently in androgensensitive versus castration-resistant human prostate cancer cells," International Journal of Environmental Research and Public Health, vol. 12, no. 7, pp. 7506-7518, 2015.

[29] S. Susilowati, T. Sardjito, I. Mustofa, O. S. Widodo, and R. Kurnijasanti, "Effect of green tea extract in extender of Simmental bull semen on pregnancy rate of recipients," Animal Bioscience, vol. 34, no. 2, pp. 198-204, 2021.

[30] S. Breton, A. V. Nair, and M. A. Battistone, "Epithelial dynamics in the epididymis: role in the maturation, protection, and storage of spermatozoa," Andrology, vol. 7, no. 5, pp. 631-643, 2019.

[31] P. Y. Wu, E. Scarlata, and C. O'Flaherty, "Long-term adverse effects of oxidative stress on rat epididymis and spermatozoa," Antioxidants (Basel), vol. 9, no. 2, pp. 1-16, 2020.

[32] W. Zhou, G. N. De Iuliis, M. D. Dun, and B. Nixon, "Characteristics of the epididymal luminal environment responsible for sperm maturation and storage," Frontiers in Endocrinology, vol. 9, p. 59, 2018.

[33] E. Saddein, T. Haghpanah, S. N. Nematollahi-Mahani, F. Seyedi, and M. Ezzatabadipour, "Preventative effects of vitamin $\mathrm{E}$ on testicular damage and sperm parameters in the first-generation mice pups due to pre- and postnatal mancozeb exposure," Journal of Toxicology, vol. 2019, no. 8, pp. 1-12, 2019.

[34] A. Capasso, "Antioxidant action and therapeutic efficacy of allium sativum L,” Molecules, vol. 18, no. 1, pp. 690-700, 2013.
[35] E. B. Kurutas, "The importance of antioxidants which play the role in cellular response against oxidative/nitrosative stress: current state," Nutrition Journal, vol. 15, no. 1, pp. 71-22, 2016.

[36] M. Zubair, "Effects of dietary vitamin E on male reproductive system," Asian Pacific Journal of Reproduction, vol. 6, no. 4, pp. 145-150, 2017.

[37] A. A. Ghafarizadeh, M. Malmir, S. Naderi Noreini, T. Faraji, and Z. Ebrahimi, "The effect of vitamin E on sperm motility and viability in asthenoteratozoospermic men: in vitro study," Andrologia, vol. 53, no. 1, Article ID e13891, 2021.

[38] R. V. Fafula, O. I. Meskalo, E. I. Lychkovskyy et al., "Effect of hydrogen peroxide on $\mathrm{Na}+, \mathrm{K}+$-ATPase activity in spermatozoa of infertile men," Regulatory Mechanisms in Biosystems, vol. 8, no. 4, pp. 521-526, 2017.

[39] S. Susilowati, W. Wurlina, I. D. P. Anom Adnyana, I. Mustofa, and M. Hariadi, "Physiological study of the use of seminal bull plasma in skim milk diluent to improve quality of frozen ram semen," Eurasian Journal of BioSciences, vol. 13, no. 1, pp. 193-197, 2019.

[40] D. K. Meles, Wurlina, I. D. P. Adnyana, S. Zakaria, D. M. Sucipta Putra, and N. Suwasanti, "Efek antimitogenik fraksi alkaloid Achyranthes aspera linn. Terhadap induksi apoptosis pada mencit yang terinfeksi Mycobacterium tuberculosis," Acta Veterinaria Indonesiana, vol. 3, no. 1, pp. 8-15, 2015.

[41] I. Mustofa, S. Susilowati, W. Wurlina, T. Hernawati, and Y. Oktanella, "Green tea extract increases the quality and reduced DNA mutation of post-thawed Kacang buck sperm," Heliyon, vol. 7, no. 3, pp. e06372-8, 2021.

[42] Z. Schafer and S. Kornbluth, "The apoptosome: physiological, developmental, and pathological modes of regulation," Developmental Cell, vol. 10, no. 5, pp. 549-561, 2016.

[43] A. L. Edinger and C. B. Thompson, "Death by design: apoptosis, necrosis and autophagy," Current Opinion in Cell Biology, vol. 16, no. 6, pp. 663-669, 2004.

[44] L. Galluzzi, I. Vitale, S. A. Aaronson et al., "Molecular mechanisms of cell death: recommendations of the nomenclature committee on cell death 2018," Cell Death and Differentiation, vol. 25, no. 3, pp. 486-541, 2018.

[45] T. Liu, L. Wang, H. Chen et al., "Molecular and cellular mechanisms of apoptosis during dissociated spermatogenesis," Frontiers in Physiology, vol. 8, p. 188, 2017.

[46] S. Elmore, "Apoptosis: a review of programmed cell death," Toxicologic Pathology, vol. 35, no. 4, pp. 495-516, 2007.

[47] H. Ochi and S. Takeda, "The two sides of vitamin E supplementation," Gerontology, vol. 61, no. 4, pp. 319-326, 2015.

[48] W. Xu, G. Guo, J. Li, Z. Ding, J. Li, and W. Tan, "Activation of bcl-2-caspase-9 apoptosis pathway in the testis of asthmatic mice," PLoS One, vol. 11, no. 3, Article ID e0149353, 2016.

[49] Q. P. Peterson, D. R. Goode, D. C. West, R. C. Botham, and P. J. Hergenrother, "Preparation of the caspase- $3 / 7$ substrate Ac-DEVD-pNA by solution-phase peptide synthesis," Nature Protocols, vol. 5, no. 2, pp. 294-302, 2010.

[50] H. Gürler, E. Malama, M. Heppelmann et al., "Effects of cryopreservation on sperm viability, synthesis of reactive oxygen species, and DNA damage of bovine sperm," Theriogenology, vol. 86, no. 2, pp. 562-571, 2016.

[51] L. Manente, S. Pecoraro, E. Picillo et al., "Molecular evidence of apoptotic pathway activation in semen samples with high DNA fragmentation," In Vivo, vol. 29, no. 2, pp. 289-294, 2015.

[52] K. Negara, K. Suwiyoga, T. Pemayun et al., "The role of caspase-3, apoptosis-inducing factor, and B-cell lymphoma-2 expressions in term premature rupture of membrane," Revista 
Brasileira de Ginecologia e Obstetrícia/RBGO Gynecology and Obstetrics, vol. 40, no. 12, pp. 733-739, 2018.

[53] E. Pintus and J. L. Ros-Santaella, "Impact of oxidative stress on male reproduction in domestic and wild animals," Antioxidants, vol. 10, no. 7, p. 1154, 2021. 